\title{
Responses of polychaete Hydroides elegans life stages to copper stress
}

\author{
Zhi-Cai Xie $^{1,3}$, Nga Cheung Wong ${ }^{1}$, Pei-Yuan Qian ${ }^{2}$, Jian-Wen Qiu ${ }^{1, *}$ \\ ${ }^{1}$ Department of Biology, Hong Kong Baptist University, Kowloon Tong, Kowloon, Hong Kong, PR China \\ ${ }^{2}$ Department of Biology, The Hong Kong University of Science and Technology, Clear Water Bay, Kowloon, \\ Hong Kong, PR China
}

${ }^{3}$ Present address: State Key Laboratory of Freshwater Ecology and Biotechnology, Institute of Hydrobiology, Chinese Academy of Sciences, Wuhan, Hubei 430072, PR China

\begin{abstract}
Two experiments were performed to examine the sensitivity of Hydroides elegans to copper stress. The first experiment tested the development of 4 distinct early stages in copper solutions from 10 to $250 \mu \mathrm{g} \mathrm{l}^{-1}$. Copper significantly reduced survivorship of the newly released oocyte and trochophore stages at concentrations $\geq 10 \mu \mathrm{g} \mathrm{l}^{-1}$, and of the 2-cell and blastula stages at $\geq 25 \mu \mathrm{g}$ $\mathrm{l}^{-1}$. The $\mathrm{EC}_{50}$ values were 47, 50, 71 and $29 \mu \mathrm{g} \mathrm{Cu} \mathrm{l}^{-1}$ for the newly released oocytes, 2-cell embryos, blastulae and trochophores, respectively. After $2 \mathrm{~h}$ into the bioassay, where Isochrysis galbana was used as food for the trochophores, algal sorption resulted in a reduction in copper concentration from $32 \%$ in the $10 \mu \mathrm{g} \mathrm{l}^{-1}$ treatment to $6 \%$ in the $250 \mu \mathrm{g} \mathrm{l}^{-1}$ treatment. Duration of development did not significantly differ among the treatments, except in the oocyte to 2-cell stage where higher copper concentration resulted in longer developmental time. In the second experiment, adult $H$. elegans were exposed to copper concentrations from 125 to $4000 \mu \mathrm{g} \mathrm{l} \mathrm{l}^{-1}$ for $48 \mathrm{~h}$. Significant mortality occurred only at copper concentrations $\geq 500 \mu \mathrm{g} \mathrm{l}^{-1}$. This study thus shows that the embryogenesis and larval development of $H$. elegans are sensitive to copper stress, and that algal sorption can substantially reduce soluble copper concentration and may affect the larval toxicity result.
\end{abstract}

KEY WORDS: Hydroides $\cdot$ Polychaete $\cdot$ Copper $\cdot$ Toxicity $\cdot$ Life cycle

- Resale or republication not permitted without written consent of the publisher

\section{INTRODUCTION}

Although copper $(\mathrm{Cu})$ is essential for the metabolism of marine animals, it can become toxic at elevated concentrations (White \& Rainbow 1985). Concentrations of $\mathrm{Cu}$ are usually low in natural ecosystems (0.05 to $\left.0.25 \mu \mathrm{g} \mathrm{l}^{-1}\right)$, but can be very high in polluted coastal waters (810 to $1000 \mu \mathrm{g} \mathrm{l}^{-1}$ ) (Soegianto et al. 1999). In recent years, due to rigid control of tributyltin-containing antifouling paints in many countries, the use of $\mathrm{Cu}$ based antifouling paints has been increasing, leading to concerns of elevated $\mathrm{Cu}$ concentrations in coastal waters (Seligman \& Zirino 1998, Lorenzo et al. 2002) and animals (Claisse \& Alzieu 1993).

In order to determine the toxicity of environmental samples, many bioassays have been developed using oysters, mussels, sea urchins, sand dollars, fishes and mysids as test organisms (Chapman et al. 1995, Nipper et al. 1997, Simon \& Laginestra 1997, King \& Riddle 2001, Carr \& Nipper 2003). Such bioassays usually employ the embryos or larvae because they are sensitive to contaminants (Pechenik 1987, Rand et al. 1995), presumably due to their relatively small size, high surface area to volume ratio and undeveloped metabolic regulation mechanisms. Polychaetes have also been widely used in bioassays of chemicals and environmental samples since the 1960 s, but the test organisms have been restricted to the juveniles and adults (reviews by Reish \& Gerlinger 1997, Nipper \& Carr 2003). In a recent study, Ross \& Bidwell (2001) explored the use of embryos of the serpulid polychaete Galeolaria caespitosa in a toxicity test. The results 
have shown that the embryogenesis of G. caespitosa is much more sensitive to copper (with a $48 \mathrm{~h} \mathrm{EC} \mathrm{EC}_{50}$ of 16 to $40 \mu \mathrm{g} \mathrm{l}^{-1}$ ) than the benthic stages of most other polychaetes, which typically have an $\mathrm{EC}_{50}$ or $\mathrm{LC}_{50}$ of 100 to $1000 \mathrm{\mu g} \mathrm{l}^{-1}$, with few exceptions (Reish \& Gerlinger 1997). The sensitivity of the early development of other polychaetes, however, has not been reported.

Hydroides elegans (Haswell), a tube-building serpulid polychaete common in tropical and subtropical coastal waters (Huang \& Cai 1984), reproduces in Hong Kong throughout the year (Qiu \& Qian 1997). This species forms aggregates in shallow water and thus, is easy to collect. It is also easy to maintain in the laboratory and can be readily induced to spawn. However, how sensitive this species is to toxicants has not been assessed. Whether this species is under copper stress in some heavily polluted areas in Hong Kong is unknown, although high concentrations of copper have been reported in both the water column (up to $24.6 \mathrm{Mg} \mathrm{l}^{-1}$ ) (Wong et al. 2001) and sediment (up to $6250 \mathrm{mg} \mathrm{kg}^{-1}$ ) (Blackmore 1998). In this study, we compared the sensitivity of different developmental stages of $H$. elegans to copper stress. The data will help us determine the copper level that may adversely affect the wild population and the suitability of this species for testing the toxicity of chemicals and environmental samples.

\section{MATERIALS AND METHODS}

Adult tubeworms were collected between July and December 2003 from PVC panels $\left(100 \mathrm{~cm}^{2}\right.$ surface area) previously submerged into the water of Long Bay, Hong Kong $\left(22^{\circ} 27^{\prime}\right.$ N, $\left.114^{\circ} 23^{\prime} \mathrm{W}\right)$. Judging from the growth rate in the laboratory (Qiu \& Qian 1998) and the time between panel deployment and retrieval, the tube worms were 1.5 to 2 mo old. They were brought to the laboratory at The Hong Kong University of Science and Technology and kept in seawater aquaria. These worms were used in 2 experiments, both conducted at $24^{\circ} \mathrm{C}$ in artificial seawater (ASW) (34 psu) prepared according to a recipe in Lorenzo et al. (2002). The background $\mathrm{Cu}$ content, as measured by differential pulse anodic stripping voltammetry (DPASV) using the standard addition method (Harvey 2000) was $0.81 \pm 0.12 \mu \mathrm{g}^{-1}(\mathrm{n}=3)$.

Expt 1: early development under copper stress. The early development of Hydroides elegans (gamete to newly settled juveniles) can be divided into 4 distinct periods (gamete to 2-cell stage, 2-cell stage to blastula, blastula to trochophore and trochophore to newlysettled juvenile). This experiment consisted of 4 bioassays, each following the development of one early developmental stage to the subsequent stage. The procedures for obtaining organisms at these developmen- tal stages were the same as in Qiu \& Qian (1997). Briefly, mature adults were induced to spawn by breaking their tubes. Sperm and oocytes from 3 males and 4 females were mixed, respectively. In Expt 1A, newly released oocytes were transferred to empty petri dishes. Care was taken not to introduce more than $100 \mu \mathrm{l}$ of water into the dishes when transferring the oocytes. When this was not practical, excessive water was removed using a pipette. Ten ml of ASW containing different concentrations of $\mathrm{Cu}$ were then added to the petri dishes. Five $\mu$ l of ASW containing sperm were pipetted into the dishes. Meanwhile, other newly released oocytes were transferred into a beaker containing $600 \mathrm{ml} \mathrm{ASW}$ and $1 \mathrm{ml}$ of ASW containing sperm was pipetted into the beaker to fertilize the oocytes. When the zygotes reached the 2-cell embryos, blastulae and trochophores, they were used in Expts 1B, 1C and 1D, respectively. Embryos and larvae at each of these stages were added to $7 \mathrm{Cu}$ treatments (control seawater, 10, 25, 50, 100, 125 and $250 \mu \mathrm{g} \mathrm{Cu} \mathrm{l}^{-1}$ as $\mathrm{CuSO}_{4}$ ). In all of the 4 developmental stages, each treatment had 5 replicates and each replicate contained 20 to 35 individuals. In Expt 1A, embryonic development was checked every 30 min after sperm and oocytes were mixed, until the oocytes had undergone fertilization and cleavage or disintegrated in $6 \mathrm{~h}$. The data were used to calculate overall survivorship and duration of development. In Expt 1B, cultures were examined at $3,4,5,6,7,8,10$ and $12 \mathrm{~h}$ after the start of the experiment, until the 2-cell embryos had developed into blastulae or disintegrated. In Expt 1C, cultures were checked at 8, 10, 12 and $24 \mathrm{~h}$ after the onset of the experiment, until the blastulae had developed into trochophores or disintegrated. Expt 1D was designed to examine the effects of $\mathrm{Cu}$ concentration on the survivorship, duration of development of trochophores and percentage trochophores settled. The chrysophyte Isochrysis galbana (Clone T-ISO), cultured with a modified f/2 medium (Guillard 1975), was offered as food to the trochophores at $10^{5}$ cells $\mathrm{ml}^{-1}$. Before use, the algae were harvested by repeated centrifugation at $2800 \times g$ for $5 \mathrm{~min}$ and resuspension in ASW to remove algal culture medium that contained EDTA. The trochophores were transferred to fresh exposure media daily for a total of $8 \mathrm{~d}$. At each transfer, the numbers of surviving larvae and new-settlers were counted.

Expt 2: survival of adults under copper stress. The sensitivity of adults to copper stress was tested using non-reproductive individuals. The tubeworms were detached from a worm aggregate into individuals or groups of 2 to 3 individuals with attached tubes and were allowed to acclimate for $2 \mathrm{~d}$ in ASW. Only healthy individuals were used in the experiment. The experiment consisted of the following $8 \mathrm{Cu}$ treatments: 
control seawater, 125, 250, 500, 1000, 2000, 3000 and $4000 \mu \mathrm{g} \mathrm{Cu} \mathrm{l}^{-1}$ as $\mathrm{CuSO}_{4}$. Each treatment had 5 replicates, and each replicate had 10 individuals in $20 \mathrm{ml}$ solution. The experiment was run for $48 \mathrm{~h}$, during which no food was offered to the worms but the exposure medium was renewed after $24 \mathrm{~h}$. At the end of exposure, the survivors were counted and the data were used to calculate survivorship.

Chemical analysis. $\mathrm{Cu}$ concentration in a separate set of dishes containing the exposure media was measured by differential pulse anodic stripping voltammetry (DPASV). Measurements were taken with a Metrohm 693 VA processor coupled with a Metrohm 694 VA Stand. A hanging mercury drop electrode was used as working electrode. The potentials were measured with an $\mathrm{Ag} / \mathrm{AgCl}$ reference electrode and an auxiliary platinum electrode. Samples were stirred at $3000 \mathrm{rpm}$ and degassed by nitrogen for $5 \mathrm{~min}$ before measurement. The potential was $-170 \mathrm{mV} \pm 35 \mathrm{mV}$ and the deposition time was $60 \mathrm{~s}$.

ASW was spiked with a $\mathrm{CuSO}_{4}$ stock solution to different $\mathrm{Cu}$ concentrations. In Expts $1 \mathrm{~A}-\mathrm{C}$, the solution was acidified to $\mathrm{pH} 1.5$ with nitric acid 2 and $24 \mathrm{~h}$ after the start of the bioassay. In Expt 1D, Isochrysis galbana was added into the culture vessels before the addition of $\mathrm{CuSO}_{4}$ solution to reach a final concentration of $10^{5}$ cells ml ${ }^{-1}$. After 2 and $24 \mathrm{~h}$, the samples were centrifuged at $3500 \mathrm{rpm}$ for $10 \mathrm{~min}$ to precipitate the algae. The supernatant was poured into another container, acidified to $\mathrm{pH} 1.5$ with nitric acid and analyzed after $3 \mathrm{~h}$ of stabilization.

Statistical analysis. Relationship between nominal $\mathrm{Cu}$ concentration and measured $\mathrm{Cu}$ concentration was assessed with linear correlation. Data of survivorship, percentage reaching settlement and duration of development were assessed for normality with the Shapiro \& Wilk Test (Zar 1999). Since none of the data met the normality assumption for parametric analysis, they were analyzed using nonparametric statistics. This was done by transforming the values to ranks and then applying parametric statistics on the ranks, as described in Zar (1999) and SAS (1988). Effects of Cu concentration on the survivorship, duration and percentage settlement were analyzed with a single-factor analysis of variance (ANOVA), followed by the Tukey multiple comparisons (Zar 1999). The $\mathrm{EC}_{50}$ for inhibition of embryogenesis and larval development, and $\mathrm{LC}_{50}$ for adults were calculated using the Trimmed Spearman-Karber method (Hamilton et al. 1977).

\section{RESULTS}

\section{Chemical analysis}

Table 1 shows the nominal and measured $\mathrm{Cu}$ concentrations in the exposure vessels. In Expts 1A-C and Expt 2, where the exposure media did not include algae, the measured $\mathrm{Cu}$ concentration ranged from 82 to $110 \%$ of the nominal concentration. However, the percentage was not dependent on the nominal $\mathrm{Cu}$ concentration. There was generally a slight increase in $\mathrm{Cu}$ concentration from the beginning of the experiment (Hour 2) to the time of exposure medium renewal (Hour 24). Since the measured $\mathrm{Cu}$ concentrations did not deviate much from the nominal concentrations, we calculated $\mathrm{Cu}$ toxicity based on the nominal concentrations. When algae were used to support trochophore development (Expt 1D), algal sorption resulted in a significant decline in $\mathrm{Cu}$ concentration. After $2 \mathrm{~h}, \mathrm{Cu}$ reduction ranged from $32 \%$ in the $10 \mathrm{\mu g} \mathrm{l}^{-1}$ treatment to $6 \%$ in the $250 \mu \mathrm{g} \mathrm{l}^{-1}$ treatment. In general, the percentage of reduction was inversely correlated with nominal $\mathrm{Cu}$ concentration (reduction \% $=-0.098 \mathrm{Cu}$ concentration $\left.+26.030, \mathrm{r}^{2}=0.74, \mathrm{p}<0.05\right)$. Except in the $25 \mu \mathrm{g} \mathrm{Cu} \mathrm{l}^{-1}$ treatment, there was a further reduction $(2.4$ to $11.7 \%)$ in $\mathrm{Cu}$ concentration from Hour 2 to Hour 24. Since the values were not stable during the course of the experiment, we were unable to express $\mathrm{Cu}$ toxicity using measured concentrations.

Table 1. Nominal and measured $\mathrm{Cu}$ concentrations $\left(\mu \mathrm{g} \mathrm{l}^{-1}\right)$ in the exposure vessels 2 and $24 \mathrm{~h}$ after setting up the experiment. Data are the mean of 3 measurements \pm SD. In Expts $1 \mathrm{~A}-\mathrm{C}$ and Expt 2, no algae were added to the exposure vessels. In Expt 1D, the concentration of Isochrysis galbana was $10^{5} \mathrm{cells} \mathrm{ml}^{-1}$

\begin{tabular}{|c|c|c|c|c|c|c|c|}
\hline \multirow[t]{2}{*}{ Nominal } & \multicolumn{2}{|c|}{$\begin{array}{c}\text { Expts } 1 \mathrm{~A}-\mathrm{C} \\
\text { Measured }\end{array}$} & \multicolumn{2}{|c|}{$\begin{array}{l}\text { Expt 1D } \\
\text { Measured }\end{array}$} & \multirow[t]{2}{*}{ Nominal } & \multicolumn{2}{|c|}{$\begin{array}{c}\text { Expt } 2 \\
\text { Measured }\end{array}$} \\
\hline & Hour 2 & Hour 24 & Hour 2 & Hour 24 & & Hour 2 & Hour 24 \\
\hline 10 & $8.2 \pm 0.4$ & $10.3 \pm 0.2$ & $6.8 \pm 0.4$ & $5.6 \pm 0.7$ & 250 & $253.5 \pm 35.6$ & $260.1 \pm 3.7$ \\
\hline 25 & $21.1 \pm 1.8$ & $22.8 \pm 0.5$ & $19.1 \pm 0.1$ & $20.3 \pm 0.3$ & 500 & $470.4 \pm 12.3$ & $499.7 \pm 14.5$ \\
\hline 50 & $45.8 \pm 3.3$ & $46.6 \pm 0.2$ & $39.7 \pm 0.6$ & $38.5 \pm 0.1$ & 1000 & $999.2 \pm 31.3$ & $1097.9 \pm 27.3$ \\
\hline 100 & $88.6 \pm 2.2$ & $99.3 \pm 2.5$ & $89.5 \pm 0.4$ & $81.3 \pm 0.6$ & 2000 & $1928.7 \pm 14.3$ & $2026.4 \pm 70.3$ \\
\hline 125 & $117.6 \pm 0.6$ & $129.1 \pm 0.8$ & $114.4 \pm 0.9$ & $103.4 \pm 1.1$ & 3000 & $3140.4 \pm 65.3$ & $3227.8 \pm 42.6$ \\
\hline 250 & $253.5 \pm 35.6$ & $260.1 \pm 3.7$ & $234.0 \pm 3.7$ & $211.8 \pm 0.8$ & 4000 & $3885.0 \pm 16.9$ & $4126.3 \pm 24.6$ \\
\hline
\end{tabular}




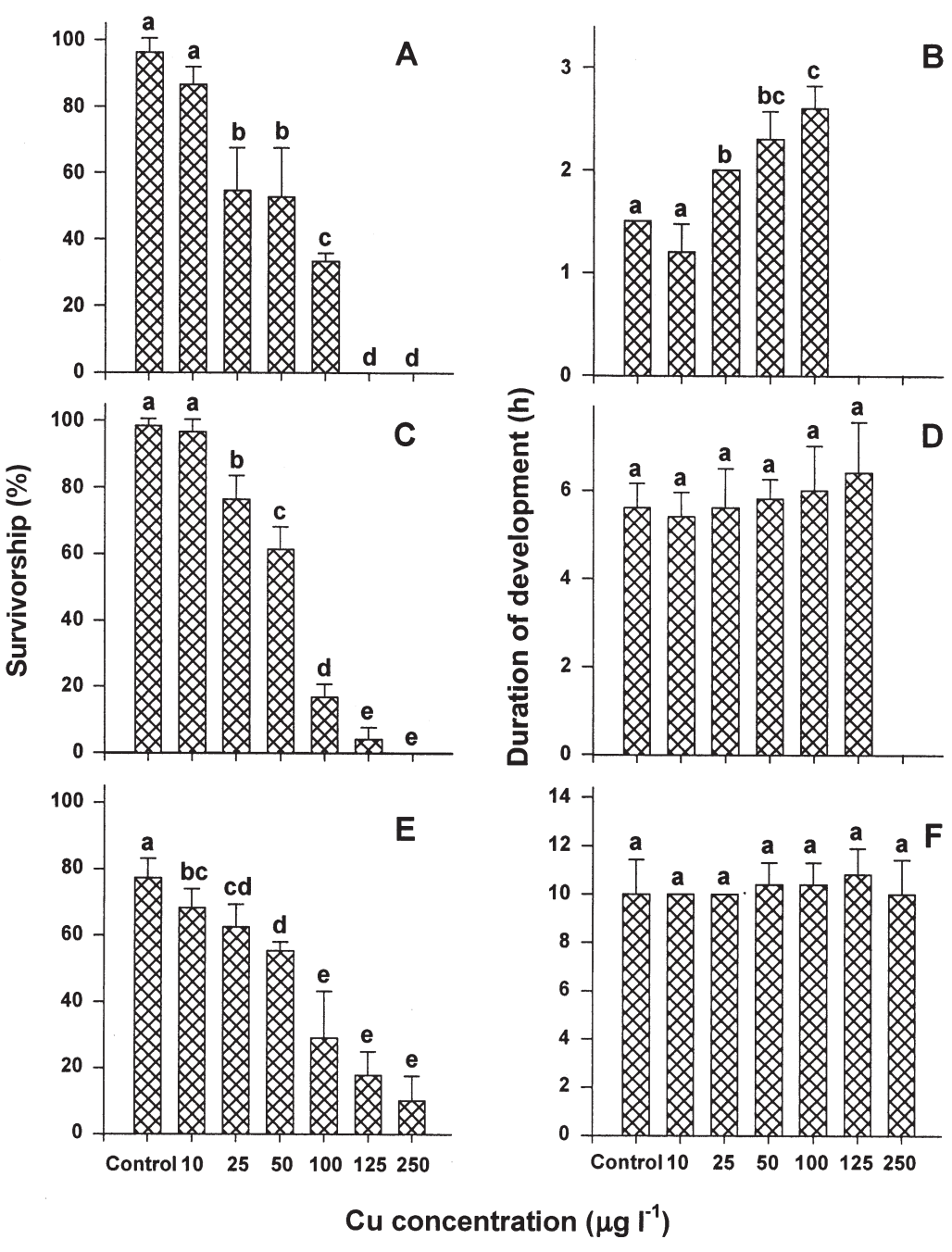

Fig. 1. Hydroides elegans. Effects of $\mathrm{Cu}$ concentration on embryonic development from $(A, B)$ newly released oocyte to the 2-cell stage, $(C, D)$ the 2-cell stage to blastula and $(\mathrm{E}, \mathrm{F})$ blastula to trochophore. The survivorship and duration of development data are mean + SD of 5 replicate cultures of 20 to 35 individuals. Bars for a certain developmental stage having the same lower case letter do not differ significantly from each other at the 0.05 level

\section{Expt 1A: newly released oocyte to 2-cell stage}

Survivorship and duration of development significantly differed among the Cu treatments (Fig. 1A,B). In the control and the $10 \mu \mathrm{g} \mathrm{Cu} \mathrm{l}^{-1}$ treatment, 96 and $87 \%$ of oocytes successfully developed into 2-cell embryos, respectively. Progressively lower percentage of oocytes reached the 2-cell stage with increasing $\mathrm{Cu}$ concentration from 25 to $100 \mu \mathrm{g} \mathrm{l}^{-1}$. In both 125 and $250 \mu \mathrm{g} \mathrm{Cu} \mathrm{l}^{-1}$ treatments, all oocytes had disintegrated by the end of the $6 \mathrm{~h}$ exposure. The $\mathrm{EC}_{50}$ for embryogenesis inhibition was $47 \mu \mathrm{g} \mathrm{Cu} \mathrm{l}^{-1}$. The duration of development was 1.5 and $1.2 \mathrm{~h}$ in the control and the $10 \mu \mathrm{g} \mathrm{Cu} \mathrm{l}^{-1}$ treatment, respectively, and was not significantly dif- ferent between the 2 treatments; it increased with increasing $\mathrm{Cu}$ concentration from $2 \mathrm{~h}$ in the $25 \mu \mathrm{g} \mathrm{l}^{-1}$ treatment to $2.6 \mathrm{~h}$ in the $100 \mu \mathrm{g} \mathrm{l}^{-1}$ treatment.

\section{Expt 1B: 2-cell stage to blastula}

$\mathrm{Cu}$ concentration significantly affected the survivorship (Fig. 1C). In the control and the $10 \mu \mathrm{g} \mathrm{Cu} \mathrm{l}^{-1}$ treatment, over $95 \%$ of the 2-cell embryos developed into blastulae. From 25 to $125 \mu \mathrm{g} \mathrm{Cu} \mathrm{l}{ }^{-1}$, progressively lower percentages ( 71 to $4 \%$ ) of the 2-cell embryos developed into blastulae. All individuals died in the $250 \mu \mathrm{g} \mathrm{Cu} \mathrm{l}^{-1}$ treatment. At 100 and $125 \mu \mathrm{g} \mathrm{Cu} \mathrm{l}{ }^{-1}$, the surviving blastulae swam very sluggishly and near the bottom of the dish. In other treatments, the blastulae swam actively and randomly in the dish. The $\mathrm{EC}_{50}$ was $50 \mu \mathrm{g} \mathrm{Cu} \mathrm{l}^{-1}$. The duration of development ranged from 4.8 to $5.5 \mathrm{~h}$ and was not significantly different among the $\mathrm{Cu}$ treatments (Fig. 1D).

\section{Expt 1C: blastula to trochophore}

Survivorship decreased with increasing $\mathrm{Cu}$ concentration (Fig. 1E). In the control, $77 \%$ of the blastulae developed into trochophores. From 10 to $250 \mu \mathrm{g} \mathrm{Cu} \mathrm{l}^{-1}$, progressively lower percentages (68 to $10 \%$ ) of the blastulae developed into trochophores. At $50 \mathrm{\mu g} \mathrm{l}^{-1}$ and lower $\mathrm{Cu}$ concentrations, the trochophores swam actively and randomly in the dish. In the higher Cu concentration treatments, the trochophores swam sluggishly and near the bottom of the dish. The $\mathrm{EC}_{50}$ was $71 \mathrm{\mu g} \mathrm{Cu} \mathrm{l}^{-1}$. The duration of development ranged from 10.4 to $10.8 \mathrm{~h}$ and was not significantly different among the $\mathrm{Cu}$ treatments (Fig. 1F).

\section{Expt 1D: trochopore to newly settled juvenile}

Percentage survival differed significantly among the $\mathrm{Cu}$ treatments (Fig. 2). At the end of the experiment, approximately $75 \%$ of the individuals in the control remained alive. Percentage survival progressively decreased from $64 \%$ in the $10 \mu \mathrm{g} \mathrm{Cu} \mathrm{l}^{-1}$ treatment to $49 \%$ in the $50 \mu \mathrm{g} \mathrm{Cu} \mathrm{l}^{-1}$ treatment. The trochophores in the $100 \mu \mathrm{Cu} \mathrm{l}^{-1}$ and higher $\mathrm{Cu}$ concentration treatments 

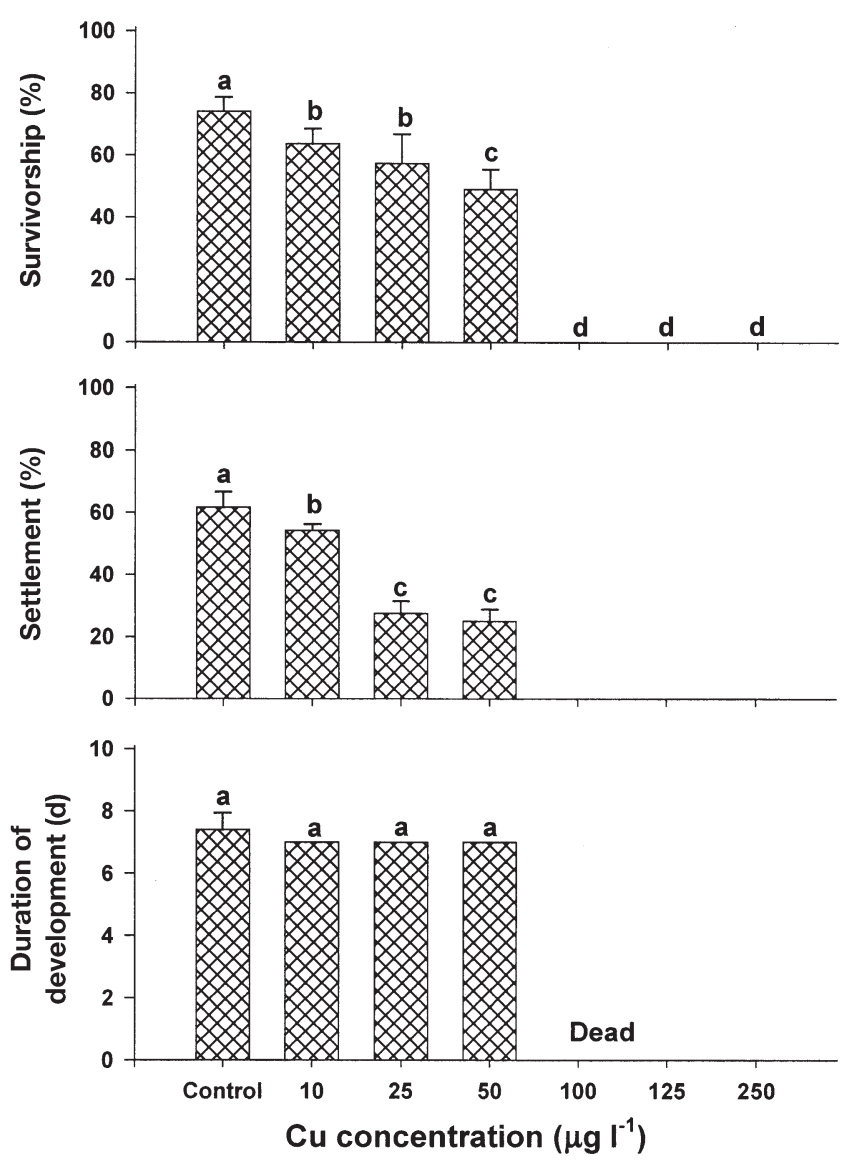

Fig. 2. Hydroides elegans. Expt 1D: effects of $\mathrm{Cu}$ concentration on survivorship, percentage reaching settlement and duration of development from trochophore to newly settled juvenile. Trochophores all died in the 100, 125 and $250 \mu \mathrm{g} \mathrm{Cu}$ $\mathrm{l}^{-1}$ treatments. Data are mean $+\mathrm{SD}$ of 5 replicate cultures of 20 to 35 individuals. Bars having the same lower case letter do not differ significantly from each other at the 0.05 level

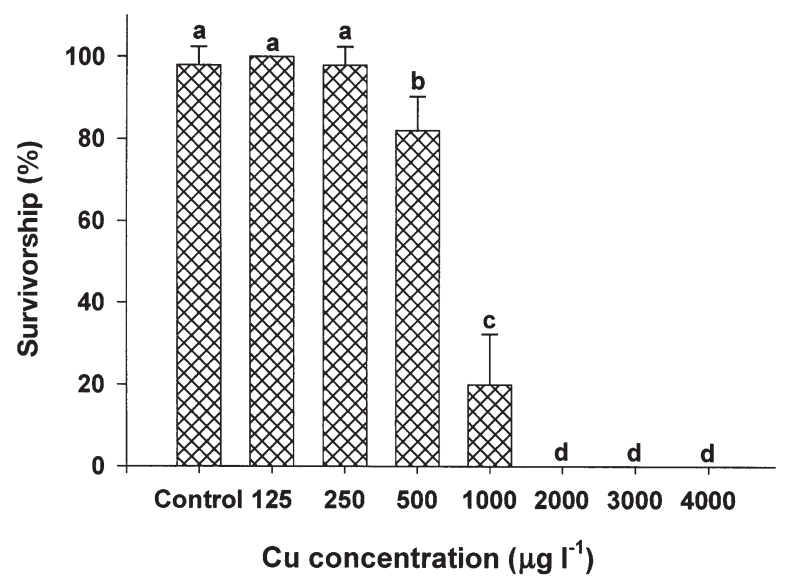

Fig. 3. Hydroides elegans. Expt 2: effects of Cu concentration on adult survival. Adults all died in the $2000 \mathrm{\mu g} \mathrm{l}^{-1}$ and higher $\mathrm{Cu}$ concentration treatments. Data are mean + SD of 5 replicate cultures of 10 individuals. Bars having the same lower case letter do not differ significantly from each other at the 0.05 level did not survive through the $8 \mathrm{~d}$ experiment. The $\mathrm{LC}_{50}$ for survival was $52 \mu \mathrm{g} \mathrm{Cu} \mathrm{l}^{-1}$. Percentage reaching settlement also significantly differed among $\mathrm{Cu}$ treatments (Fig. 2). In the control and $10 \mu \mathrm{g} \mathrm{Cu} \mathrm{l}{ }^{-1}$ treatment, over $50 \%$ of the trochophores successfully settled and metamorphosed into juveniles. In the 25 and $50 \mu \mathrm{g} \mathrm{Cu} \mathrm{l}^{-1}$ treatments, only approximately $25 \%$ of the larvae developed into juveniles. These juveniles, however, appeared to have normal body and tentacular structures, and exhibited normal feeding activities. The $\mathrm{EC}_{50}$ for settlement inhibition was $29 \mu \mathrm{g} \mathrm{Cu} \mathrm{l}^{-1}$. The development from trochophore to newly settled juvenile took 7.0 to $7.4 \mathrm{~d}$ and was not significantly different among the $\mathrm{Cu}$ treatments.

\section{Expt 2: survival of adults}

$\mathrm{Cu}$ concentration significantly affected survival of the adults during the $48 \mathrm{~h}$ exposure period (Fig. 3). In the control and $\mathrm{Cu}$ concentration treatments up to $250 \mathrm{\mu g} \mathrm{l}^{-1}$, the survivorship was high (>98\%), and the difference among these 3 treatments was insignificant. From 500 to $1000 \mathrm{\mu g} \mathrm{Cu} \mathrm{l}^{-1}$, the survivorship declined sharply from 82 to $20 \%$. No surviving worms were found at $\mathrm{Cu}$ concentrations higher than $1000 \mu \mathrm{g} \mathrm{l}^{-1}$. The $\mathrm{LC}_{50}$ was $715 \mu \mathrm{g} \mathrm{Cu} \mathrm{l^{-1 }}$.

\section{DISCUSSION}

Polychaetes have been used in testing the toxicity of pure chemicals and sediment samples since the 1960s. According to Reish \& Gerlinger 1997, 48 species in 20 families of polychaetes have been used as test organisms, with members of families Capitellidae, Dinophilidae, Dorvilleidae and Nereididae being the most frequently used species. The majority of these bioassays used juvenile or adult stages, whereas the sensitivity of the embryonic and larval stages of polychaetes remains largely unknown. In this study, we reported the ontogenetic changes in tolerance to $\mathrm{Cu}$ in a serpulid polychaete, Hydroides elegans. The results showed that the $\mathrm{EC}_{50}$ values were $47,50,71$ and $29 \mu \mathrm{g}$ $\mathrm{Cu} \mathrm{l}^{-1}$ for the development of the newly released oocyte, 2-cell stage, blastula and trochophore, respectively. The $48 \mathrm{~h} \mathrm{LC}_{50}$ for the adults was $715 \mu \mathrm{g} \mathrm{Cu} \mathrm{l}{ }^{-1}$. A comparison between these toxicity values with the highest reported $\mathrm{Cu}$ concentration in Hong Kong waters $\left(24.6 \mu \mathrm{g} \mathrm{l}^{-1}\right.$, in Wong et al. 2001) indicates that the wild $H$. elegans population is unlikely to be under copper stress. The results also indicate that the embryos and larvae of $H$. elegans were 10 to 25 times as sensitive as the adults to $\mathrm{Cu}$ stress. The $\mathrm{EC}_{50}$ values for the early developmental stages of $H$. elegans were 
comparable with the result of Ross \& Bidwell (2001) on the embryos of G. caespitosa, suggesting that the early development of both serpulid polychaetes is of similar sensitivity to $\mathrm{Cu}$ stress. It should also be noted that the experimental durations for the 4 early stages were different. The experiment starting with oocytes, 2-cells and blastulae, lasting for 6,12 and $24 \mathrm{~h}$, respectively, resulted in similar $\mathrm{EC}_{50}$ values (around $50 \mathrm{\mu g} \mathrm{Cu}^{-1}$ ). Compared with these values, the $\mathrm{EC}_{50}$ from trochophores was lower $\left(29 \mathrm{~g} \mathrm{Cu}^{-1}\right)$, indicating that trochophores are more sensitive to copper stress than the other 3 embryonic stages. However, the experimental duration was much longer $(10 \mathrm{~d})$, which should be taken into account when selecting a developmental stage for toxicity testing.

Sensitivity to pollutants depends on the type of organisms and the stage of development used. The embryos and larvae of bivalves, such as mussels and oysters, have been widely used in toxicity tests, partly because of their high sensitivity. His et al. (1999) conducted a comprehensive review of the assessment of marine pollution using bivalve embryos and larvae as testing organisms. They found that the sensitivity was comparable among different bivalve species, but varied dramatically with developmental stage in a given species. Among the early developmental stages of a species, embryos were usually more sensitive than larvae. The average $\mathrm{EC}_{50}$ for inhibition of mollusk embryogenesis was $39.8 \mathrm{\mu g} \mathrm{l}^{-1}$ and the average $\mathrm{LC}_{50}$ for larval mortality was $86.5 \mu \mathrm{g} \mathrm{l}^{-1}$. The embryos of sea urchins were also very sensitive to $\mathrm{Cu}$. For example, the $48 \mathrm{~h} \mathrm{EC}_{50}$ for inhibition of embryogenesis was 32 to $100 \mathrm{\mu g} \mathrm{l}^{-1}$ in Paracentrotus lividus (Kobayashi 1981, Pagano et al. 1986, Fernández \& Beiras 2001, Lorenzo et al. 2002), 31 to $44 \mu_{\mathrm{g} \mathrm{l}} \mathrm{l}^{-1}$ in Arbacia punctulata (Carr 1996) and $43 \mu \mathrm{g} \mathrm{l}^{-1}$ in Diadema setosum (Ramachandran et al. 1997). A comparison of the above $\mathrm{EC}_{50}$ values with those of Hydroides elegans showed that the polychaete embryos and larvae have comparable levels of sensitivity to $\mathrm{Cu}$ stress.

In this study, we explored the sensitivity of the early development of Hydroides elegans using the following endpoints: mortality, duration of a developmental stage and percentage larval settlement. These endpoints were easy to quantify, but not all of them were suitable for use in routine testing. Significant mortality of the oocytes and trochophores occurred in the $\geq 10 \mu \mathrm{g}$ $\mathrm{Cu}^{-1}$ treatments, and of the 2-cell embryos and blastulae in the $\geq 25 \mu \mathrm{g} \mathrm{Cu} \mathrm{l}^{-1}$ treatments. The doseresponse curves were gradual over a relatively wide range of $\mathrm{Cu}$ concentrations, resulting in the $\mathrm{EC}_{50}$ of $47,50,71$ and $29 \mu \mathrm{g} \mathrm{Cu} \mathrm{l}^{-1}$ for the newly released oocytes, 2-cell embryos, blastulae and trochophores, respectively. Mortality is, thus, sensitive and can be used as an endpoint in toxicity tests. However, it is inappropriate to use duration of development as an endpoint to assess the toxicity of $\mathrm{Cu}$ in this species. The duration of development was not significantly different among the $\mathrm{Cu}$ treatments, except in Expt $1 \mathrm{~A}$, where the duration of development lengthened with increasing $\mathrm{Cu}$ concentration. But in Expt $1 \mathrm{~A}$, the toxicological effect had to be observed in a short period of time due to the brief developmental time (1.2 to $2.5 \mathrm{~h})$ from oocyte to 2-cell embryo.

The trochophores require feeding in order to complete larval development. In larval toxicity tests, algae not only serve as food, but also provide binding sites for toxicants. Although algae are routinely used in the culture of invertebrate larvae (His \& Robert 1981, Watling 1982, Beaumont et al. 1987), the effect of metal sorption by algae on the toxicity result has not been assessed. Obviously, the extent of algal sorption depends on the algal concentration and the metal concentration. In this study, we fed the trochophores with Isochrysis galbana at $10^{5}$ cells ml-1. By Hour 2, the $\mathrm{Cu}$ concentration was reduced by $32 \%$ in the $10 \mu \mathrm{g} \mathrm{l}^{-1}$ treatment and $6 \%$ in the $250 \mu \mathrm{g}$ $\mathrm{I}^{-1}$. The reduction in $\mathrm{Cu}$ concentration in the aqueous phase might have affected the toxicity result because the reported $\mathrm{EC}_{50}\left(29 \mu \mathrm{g} \mathrm{Cu} \mathrm{l}^{-1}\right)$ was calculated using nominal $\mathrm{Cu}$ concentrations. Should the measured $\mathrm{Cu}$ concentrations have been used, the $\mathrm{EC}_{50}$ value would have been approximately $30 \%$ lower $\left(21.4 \mu \mathrm{g} \mathrm{Cu} \mathrm{l^{-1 }}\right.$ based on the measured $\mathrm{Cu}$ concentrations at Hour 2, and $20.2 \mu \mathrm{g} \mathrm{Cu} \mathrm{l}^{-1}$ based on the measured $\mathrm{Cu}$ concentrations at Hour 24). Although the measured $\mathrm{Cu}$ concentrations were unstable over time, the data indicate that when algae are used to feed animals in toxicity tests, algal sorption could result in a significant decline in toxicant concentration in the aqueous phase. When nominal toxicant concentrations are low, a large proportion of the toxicant might be bound to the algae, resulting in underestimation of the toxicity. Further studies should quantify such sorption effects with different algal species and algal concentrations.

In addition to sensitivity to toxicants, environmental relevance and ease of maintenance of an organism are also among the criteria for selecting species for routine bioassays. Hydroides elegans is widely distributed along the coasts of Australia, New Zealand, Singapore, Southern Japan, Southern China, Egypt, India, California, Hawaii, the English Channel and the Bristol Channel (ten Hove 1974, Huang \& Cai 1984, Bastida-Zavala \& ten Hove 2002). The ubiquitous distribution of $H$. elegans in tropical and subtropical waters indicates that it is a common receiver of pollutants in coastal waters. In Hong Kong, this species reproduces throughout the year, making it possible to obtain gametes for embryonic work in all 
seasons. Furthermore, because this species is less than $2.5 \mathrm{~cm}$ in body length, hundreds of individuals can be cultured in a small aquarium. We maintained a population of $H$. elegans from 1997 to 1998 in a 201 aquarium by feeding the worms with a mixture of Isochrysis galbana and Chaetoceros muelleri, during which the worms were sampled from time to time. Reproductive individuals approximated 25 to $50 \%$ at each sampling, offering sufficient gametes for conducting experiments. Compared with oysters and other bivalves, this species requires less laboratory space to keep.

Exposure duration is another criterion to consider when developing bioassays. Under optimal laboratory conditions, the whole life-cycle of Hydroides elegans can be completed in approximately $22 \mathrm{~d}$, including less than $1 \mathrm{~d}$ for embryogenesis, $5 \mathrm{~d}$ for larval development and $16 \mathrm{~d}$ for growth and maturation (Qiu \& Qian 1997, 1998). Although the duration of embryogenesis is also short in bivalves and sea urchins (several hours to $1 \mathrm{~d}$ ), the duration of their larval development is quite long (usually a month or longer) and the duration from settlement to maturation is even longer (usually more than 1 yr) (Seed \& Brown 1977, Strathmann 1987, Qiu et al. 2002). As a result of financial and labor constraints imposed by the chronic bioassay, most toxicity tests with bivalve larvae only lasted for 2 to $15 \mathrm{~d}$ (Table 10 in His et al. 1999), without even allowing the larvae to develop to the eyed-veliger stage. A similar situation occurs in bioassays using sea urchin larvae as the test organisms, where the larvae are generally maintained only for 3 to $4 \mathrm{~d}$ (Chapman et al. 1995), which is too short a time period in which to complete larval development. The short life-cycle in $H$. elegans, thus, offers the potential for testing of not only acute toxicity to embryonic and larval stages, but also sublethal growth and reproductive responses in the whole larval and juvenile stages within a relatively short period of time.

In summary, this study has shown that, in Hong Kong waters, environmental $\mathrm{Cu}$ levels may not negatively affect any of the developmental stages of Hydroides elegans. Within the life cycle, embryos and larvae are much more sensitive to $\mathrm{Cu}$ stress than adults. Among different biological responses measured, mortality provides a gradual dose-response relationship and can be used as an endpoint in a toxicity test. Duration of development, however, does not correlate well with $\mathrm{Cu}$ concentration and thus, is not a suitable toxicity endpoint.

Acknowledgements. The authors thank C. W. Chau and T. Jing for technical support, and 5 anonymous reviewers for comments and criticisms on the manuscript. This study was supported by a grant from Hong Kong Baptist University to J.-W.Q.

\section{LITERATURE CITED}

Bastida-Zavala JR, ten Hove HA (2002) Revision of Hydroides Gunnerus, 1768 (Polychaeta: Serpulidae) from the western Atlantic region. Beaufortia 52:103-178

Beaumont AR, Tserpes G, Budd MD (1987) Some effects of copper on the veliger larvae of the mussel Mytilus edulis and the scallop Pecten maximus (Mollusca Bivalvia). Mar Environ Res 21:299-309

Blackmore G (1998) An overview of trace metal pollution in the coastal waters of Hong Kong. Sci Total Environ 214:21-48

Carr RS (1996) Sediment quality assessment studies of Tampa Bay, Florida. Environ Toxicol Chem 15:1218-1231

Carr RS, Nipper M (2003) Historical overview of porewater toxicity testing. In: Carr RS, Nipper M (eds) Porewater toxicity testing: biological, chemical, and ecological considerations. SETAC Press, Pensacola, FL, p 1-10

Chapman GA, Denton DL, Lazorchak JM (1995) Short-term methods for estimating the chronic toxicity of effluents and receiving waters to west coast marine and estuarine organisms, 1st edn. EPA/600/R-95-136. US Environmental Protection Agency, Washington, DC

Claisse D, Alzieu CL (1993) Copper contamination as a result of antifouling paint regulations? Mar Pollut Bull 26: 395-397

Fernández N, Beiras R (2001) Combined toxicity of dissolved mercury with copper, lead and cadmium on embryogenesis and early larval growth of the Paracentrotus lividus sea-urchin. Ecotoxicology 10:263-271

Guillard RRL (1975) Culture of phytoplankton for feeding marine invertebrates. In: Smith WL, Chanley MH (eds) Culture of marine invertebrate animals. Plenum Publishing, New York, p 29-60

Hamilton MA, Russo RC, Thurston RV (1977) Trimmed Spearman-Karber method for estimating median lethal concentrations in toxicity bioassays. Environ Sci Tech 11:714-719

Harvey D (2000) Modern analytical chemistry. McGraw-Hill Higher Education, Singapore

His E, Robert R (1981) Effects of copper chloride on the eggs and D larvae of Crassostrea gigas (Thunberg). Preliminary results. Conseil International pour l'Exploration de la Mer, Mariculture Committee, C.M. 1981/F: 43, p 1-14

His E, Beiras R, Seaman MNL (1999) The assessment of marine pollution-bioassays with bivalve embryos and larvae. In: Southward AJ, Tyler PA, Young CM (eds) Advances in marine biology. Academic Press, San Diego, CA, p 1-178

Huang ZG, Cai RX (1984) Marine fouling organisms and their control, Vol 1. Oceanic Press, Beijing

King CK, Riddle MJ (2001) Effects of metal contaminants on the development of the common Antarctic sea urchin Sterechinus neumayeri and comparisons of sensitivity with tropical and temperate echinoids. Mar Ecol Prog Ser 215:143-154

Kobayashi N (1981) Comparative toxicity of various chemicals, oil extracts and oil dispersant extracts to Canadian and Japanese sea urchin eggs. Publ Seto Mar Biol Lab 26: 123-133

Lorenzo JI, Nieto O, Beitas R (2002) Effect of humic acids on speciation and toxicity of copper to Paracentrotus lividus larvae in seawater. Aquat Toxicol 58:27-41

Nipper M, Carr RS (2003) Recent advances in the use of meiofaunal polychaetes for ecotoxicological assessments. Hydrobiologia 496:347-353

Nipper MG, Martin ML, Williams EK (1997) The optimization and validation of a marine toxicity test using the New 
Zealand echinoid, Fellaster zelandiae. Aust J Ecotox 3: 109-116

Pagano G, Cipollaro M, Corsale G, Esposito A, Ragucci E, Giordano GG, Trieff NM (1986) The sea urchin bioassay for the assessment of damage from environmental contaminants. In: Caines JJr (ed) Community toxicology testing. ASTM STP 920. American Society for Testing and Materials, Philadelphia, PA, p 66-92

Pechenik JA (1987) Environmental influences on larval development. In: Giese AC, Pearse JS, Pearse VB (eds) Reproduction of marine invertebrates, Vol 9. Blackwell Scientific Publications, Palo Alto, CA, p 551-608

Qiu JW, Qian PY (1997) Combined effects of salinity, temperature and food on early development of the polychaete Hydroides elegans. Mar Ecol Prog Ser 152:79-88

Qiu JW, Qian PY (1998) Combined effects of salinity and temperature on juvenile survival, growth and maturation in the polychaete Hydroides elegans. Mar Ecol Prog Ser 168: 127-134

Qiu JW, Tremblay R, Bourget E (2002) Ontogenetic changes in hyposaline tolerance in the mussels Mytilus edulis and M. trossulus: implications for distribution. Mar Ecol Prog Ser 228:143-152

Ramachandran S, Patel TR, Colbo MH (1997) Effect of copper and cadmium on three Malaysian tropical estuarine invertebrate larvae. Ecotoxicol Environ Saf 36:183-188

Rand GM, Wells PG, Mcarty LS (1995) Introduction to aquatic toxicology. In: Rand GM (ed) Fundamentals of aquatic toxicology. Effects, environmental fate and risk assessment. Taylor \& Francis, Washington, DC, p 3-70

Reish DJ, Gerlinger TV (1997) A review of the toxicological studies with polychaetous annelids. Bull Mar Sci 60: 584-607

Ross KE, Bidwell JR (2001) A 48-h larval development toxicity test using the marine polychaete Galeolaria caespitosa Lamarck (Fam. Serpulidae). Arch Environ Contam Toxicol 40:489-496

Editorial responsibility: Otto Kinne (Editor-in-Chief), Oldendorf/Luhe, Germany
SAS (1988) SAS/STAT user's guide, release 6.03 edn. SAS Institute, Cary, NC

Seed R, Brown RA (1977) A comparison of the reproductive cycles of Modiolus modiolus (L.), Cerastoderma (=Cardium) edule (L.) and Mytilus edulis (L.) in Strangford Lough, Northern Ireland. Oecologia 30:173-188

Seligman PF, Zirino A (1998) Chemistry, toxicity, and bioavailability of copper and its relationship to regulation in the marine environment. Technical Document 3044, Office of Naval Research, San Diego, CA

Simon J, Laginestra E (1997) Bioassay for testing sublethal toxicity in effluents, using gametes of sea urchin Heliocidaris tuberculata. National Pulp Mills Research Program Technical Report no. 20, CSIRO, Canberra

Soegianto A, Charmantier-Daures M, Trilles JP, Charmantier G (1999) Impact of copper on the structure of gills and epipodites of the shrimp Penaeus japonicus (Decapoda). J Crustac Biol 19:209-223

Strathmann MF (1987) Reproduction and development of marine invertebrates of the northern Pacific coast. Data and methods for the study of eggs, embryos, and larvae. University of Washington Press, Seattle, WA

ten Hove HA (1974) Notes on Hydroides elegans (Haswell, 1883) and Mercierella enigmatica Fauvel, 1923, alien serpulid polychaetes introduced into the Netherlands. Bull Zool Mus Univ Amst 4:45-51

Watling HR (1982) Comparative study of the effects of zinc, cadmium and copper on the larval growth of three oyster species. Bull Environ Contamin Toxicol 28:195-201

White SL, Rainbow PS (1985) On the metabolic requirements for copper and zinc in molluscs and crustaceans. Mar Environ Res 16:215-229

Wong CK, Wong PP, Chu LM (2001) Hevy metal concentrations in marine fishes collected from fish culture sites in Hong Kong. Arch Environ Contam Toxicol 40:60-69

Zar JH (1999) Biostatistical analysis, 4th edn. Prentice Hall, Upper Saddle River, NJ

Submitted: March 15, 2004; Accepted: July 1, 2004

Proofs received from author(s): January 6, 2005 